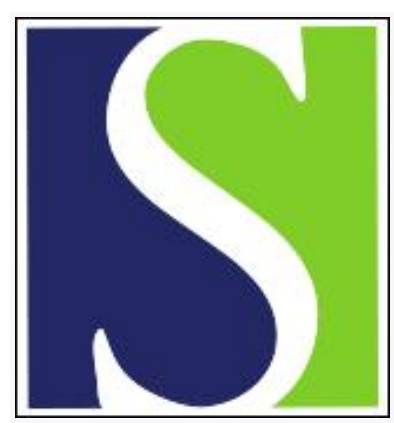

Scand J Work Environ Health 1985;11(5):347-352

https://doi.org/10.5271/sjweh.2214

Issue date: Oct 1985

Mortality of styrene production, polymerization and processing workers at a site in northwest England.

by Hodgson JT, Jones RD

This article in PubMed: www.ncbi.nlm.nih.gov/pubmed/4070999

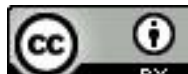




\title{
Mortality of styrene production, polymerization and processing workers at a site in northwest England
}

\author{
by John T Hodgson, MSc, Robert D Jones, MSc, MRCS, LRCP ${ }^{1}$
}

\begin{abstract}
HODGSON JT, JONES RD. Mortality of styrene production, polymerization and processing workers at a site in northwest England. Scand J Work Environ Health 11 (1985) 347-352. The mortality of 622 men who worked for at least one year in the production, polymerization, and processing of styrene at a chemical site in the United Kingdom during the period 1945-1974 was surveyed up to the end of 1978; 3072 male manual workers at the same site but unexposed to styrene were also studied. A statistically significant excess of lymphoma deaths was found in the exposed population, and two of the three deaths observed occurred in men less than 40 years of age. The small number of deaths and the lack of any evidence for an association with duration or level of exposure to styrene are reasons for interpreting this result cautiously. However, the otherwise normal pattern of mortality in the exposed population and the absence of any excess of lymphomas in the reference group lend some support to suggestions that exposure to styrene may be associated with lymphomas in man. An analysis of cancer registrations for the exposed population revealed no further cases of lymphoma but identified one case of lymphatic leukemia. An excess of laryngeal cancer registrations was found. As this effect has not been previously postulated and because of the small number of registrations, too much weight should not be attached to this one observation.
\end{abstract}

Key terms: laryngeal cancer, lymphoma, solvents.

The reported study was set up in 1974 by the Health and Safety Executive. It was supported by the company employing the study population, and it followed a request from the trade unions through the company's safety council.

The possibility that exposure to styrene might cause lymphomas and leukemia in man was suggested in 1976 by evidence (4) presented in the United States. The results of two epidemiologic studies $(2,5)$ reported since then have been inconclusive.

\section{Subjects and methods}

The population studied worked at a single chemical site in the northwest of England where styrene monomer was produced, polymerized, and processed. The company's personnel records were used to identify 622 men who were exposed to styrene for at least one year at any time during the period 1945-1974. The population included 131 men who were potentially exposed to styrene among other chemicals in laboratories. The remaining 491 individuals were male manual workers who would have had mixed chemical exposures but had a specific potential exposure to styrene in the production of styrene monomer, the polymerization of styrene, or the manufacture of finished products. An additional 3072 male manual

\footnotetext{
1 Epidemiology and Medical Statistics Unit, Health and Safety Executive, London, United Kingdom.

Reprint requests to: Mr JT Hodgson, Epidemiology and Medical Statistics Unit, Health and Safety Executive, Magdalen House, Trinity Road, Bootle, Merseyside L20 3QZ, United Kingdom.
}

workers who worked for at least one year at the same site at any time during the same period with variable chemical exposure, but who had no specific occupational exposure to styrene, were also identified and treated as a reference group. These figures exclude 2 exposed and 181 unexposed men, identified by the company, for whom insufficient identification details were available to make tracing practicable. The population was traced through the National Health Service Central Register (NHSCR), and except for $14 \mathrm{emi}-$ grants in the exposed population and 181 in the unexposed population (for whom dates of emigration were obtained), the dates of death were obtained for all deaths occurring up to 31 December 1978. Underlying causes of death were coded by staff of the Office of Population Censuses and Surveys [using the eighth revision of the International Classification of Diseases (ICD)]. The ICD revisions appropriate to the time of the study included the fifth, sixth, seventh, and eighth.

Cancer registration details for the exposed population for the period 1 January $1962^{2}$ to 31 December 1981 (including ICD codings) were obtained from the Regional Cancer Registry.

For the purposes of the mortality analyses, personyears at risk were calculated in days from the date exactly one year after first potential exposure to styrene (exposed population) or exactly one year after starting employment at that site (unexposed population) up to whichever was the earliest of the following dates: date

\footnotetext{
2 The first day of operation of the registry. The total number of "expected registrations" in the exposed population from 1947 to 1961 is 0.75 . The loss of information to the study due to the nonexistence of a cancer registration system in the early years is thus minimal.
} 
Table 1. Person-years at risk for the mortality analysis $(1945-1978)$ by age and cohort.

\begin{tabular}{|c|c|c|c|c|c|c|}
\hline & \multirow{2}{*}{$\begin{array}{c}\text { Number } \\
\text { of } \\
\text { men }\end{array}$} & \multicolumn{5}{|c|}{ Person-years at risk by age (years) group } \\
\hline & & $15-44$ & $45-54$ & $55-64$ & $\geq 65$ & Total \\
\hline \multicolumn{7}{|l|}{ Exposed population } \\
\hline $\begin{array}{l}\text { First exposed during } \\
\text { period } 1945-1958\end{array}$ & 137 & 1811.9 & 805.6 & 281.7 & 87.5 & 2986.8 \\
\hline $\begin{array}{l}\text { First exposed during } \\
\text { period } 1959-1968\end{array}$ & 323 & 3164.2 & 1170.5 & 307.0 & 49.1 & 4690.8 \\
\hline $\begin{array}{l}\text { First exposed during } \\
\text { period } 1969-1974\end{array}$ & 162 & 830.7 & 128.7 & 16.9 & 0.0 & 976.3 \\
\hline Total & 662 & 5806.9 & 2104.7 & 605.6 & 136.6 & 8653.9 \\
\hline Unexposed population & 3072 & 30607.7 & 9923.5 & 4093.6 & 996.4 & 45621.1 \\
\hline
\end{tabular}

Table 2. Deaths by cause in the exposed and unexposed populations. (ICD $=$ International Classification of Disease, SMR $=$ standardized mortality ratio)

\begin{tabular}{|c|c|c|c|c|c|c|}
\hline \multirow{2}{*}{ Cause of death (ICD code) } & \multicolumn{3}{|c|}{ Exposed Population } & \multicolumn{3}{|c|}{ Unexposed Population } \\
\hline & Observed & Expected & $\mathrm{SMR}^{\mathrm{a}}$ & Observed & Expected & SMR $^{a}$ \\
\hline All causes $(0-999)$ & 34 & 43.1 & $80(70)$ & 219 & 248.8 & $90(80)$ \\
\hline $\begin{array}{l}\text { Al! maliginant neoplasms } \\
(140-209)\end{array}$ & 10 & 10.9 & 90 & 57 & 64.1 & 90 \\
\hline $\begin{array}{l}\text { Cancer of the esophagus } \\
\text { (150) }\end{array}$ & 1 & 0.3 & - & - & 1.7 & - \\
\hline $\begin{array}{l}\text { Cancer of the trachea, } \\
\text { bronchus and lung (162) }\end{array}$ & 5 & 4.2 & - & 24 & 26.0 & $90(80)$ \\
\hline Lymphoma (200-202) & $3^{\mathrm{b}}$ & 0.56 & - & 3 & 3.02 & - \\
\hline Leukemia (204-207) & - & 0.3 & - & - & 1.5 & - \\
\hline $\begin{array}{l}\text { Diseases of the circulatory } \\
\text { system }(390-458)\end{array}$ & 18 & 19.9 & $90(80)$ & 100 & 116.2 & $90(80)$ \\
\hline $\begin{array}{l}\text { Diseases of the respiratory } \\
\text { system }(460-519)\end{array}$ & 2 & 4.1 & - & 25 & 26.6 & $90(60)$ \\
\hline
\end{tabular}

a The SMR values are quoted in respect of cause-specific mortality only where 10 or more deaths have been observed, and they are rounded to reflect their wide confidence limits. Figures in parentheses give estimated SMR values adjusted for northwest regional mortality rates.

b $P_{u}=0.02$

of death, date of emigration, or 31 December 1978. The person-years at risk were calculated in five-year age groups for each quinquennial period of the study period, and the appropriate mortality rates for males in England and Wales were applied in order to calculate the numbers of expected deaths. The published rates for the ICD revisions prior to the eighth were converted to estimated eighth revision equivalents from the linkage tables published by the Office of Population Censures and Surveys. The inaccuracy introduced by this conversion is negligible since $97 \%$ of the deaths in the exposed population and $85 \%$ of the deaths in the unexposed population occurred during the currency of the eighth revision (1967-1978). Table 1 shows the person-years at risk for the mortality analysis of the exposed and unexposed populations by age and (for the exposed only) by year of first exposure to styrene. For the period 1967-1978, mortality rates (for 10-year age groups) for some causes of death were available (6) for the northwest region of England, where the site under study was located. These rates were used to calculated the numbers of expected deaths and the standardized mortality ratios for the period 1967-1978. These regionally adjusted ratios were used as good approximations to those for the entire follow-up period.

We calculated the expected values for cancer registrations by applying the age-specific registration rates to the person-years at risk of the exposed population. The rates were calculated by relating registrations (by site and age) to the population of the northwest hospital region.

\section{Results}

Comparison of cancer registry and death certificate data

Of the four lymphohematopoietic cancer registrations in the exposed population (three lymphoma, one lymphatic leukemia), two did not cite the registered cancer type as the underlying cause of death. Case 3 was recorded at the cancer registry as a non-Hodgkin's lymphoma (ICD 202.0) and on the death certificate as Hodgkin's disease (ICD 201.0). Case 4 was recorded as a chronic lymphatic leukemia at the cancer registry, but on the death certificate the underlying cause of death was recorded as hypertensive heart disease (ICD 402) with chronic lymphatic leukemia mentioned in part II of the certificate. 
Table 3. Selected causes of death in the exposed population by age. (ICD $=$ International Classification of Disease, Obs $=$ observed, $\operatorname{Exp}=$ expected, $P_{u}=$ upper tail of distribution in question, $P_{1}=$ lower tail of distribution in question)

\begin{tabular}{|c|c|c|c|c|c|c|c|c|}
\hline \multirow{3}{*}{ Cause of death (ICD code) } & \multicolumn{8}{|c|}{ Age (years) at death } \\
\hline & \multicolumn{2}{|c|}{$15-44$} & \multicolumn{2}{|c|}{$45-54$} & \multicolumn{2}{|c|}{$55-64$} & \multicolumn{2}{|c|}{$\geq 65$} \\
\hline & Obs & Exp & Obs & Exp & Obs & Exp & Obs & Exp \\
\hline All causes $(0-999)$ & $2^{\mathrm{a}}$ & 10.1 & 15 & 14.1 & 10 & 11.3 & 7 & 7.7 \\
\hline $\begin{array}{l}\text { All malignant neoplasms } \\
(140-209)\end{array}$ & 2 & 2.0 & 3 & 3.7 & 3 & 3.3 & 2 & 1.9 \\
\hline $\begin{array}{l}\text { Cancer of trachea, } \\
\text { bronchus and lung (162) }\end{array}$ & - & 0.4 & 2 & 1.5 & 1 & 1.5 & 2 & 0.8 \\
\hline Lymphoca $(200-202)$ & $2^{\mathrm{b}}$ & 0.27 & - & 0.15 & 1 & 0.08 & - & 0.03 \\
\hline $\begin{array}{l}\text { Diseases of the circulatory } \\
\text { system }(390-458)\end{array}$ & - & 3.3 & 10 & 7.0 & 5 & 5.6 & 3 & 3.9 \\
\hline
\end{tabular}

a $P_{1}<0.005$

b $\mathrm{P}_{\mathrm{u}}=0.032$.

Table 4. Observed and expected cancer registrations $(1967-1981)$ by age of the exposed population.

\begin{tabular}{|c|c|c|c|c|c|c|c|c|c|c|}
\hline \multirow{3}{*}{ Malignant neoplasms } & \multicolumn{8}{|c|}{ Age (years) } & & \\
\hline & \multicolumn{2}{|c|}{$15-44$} & \multicolumn{2}{|c|}{$45-54$} & \multicolumn{2}{|c|}{$55-64$} & \multicolumn{2}{|c|}{$\geq 65$} & \multicolumn{2}{|c|}{ Total } \\
\hline & $\begin{array}{l}\text { Ob- } \\
\text { served }\end{array}$ & $\begin{array}{c}\text { Ex- } \\
\text { pected }\end{array}$ & $\begin{array}{l}\text { Ob- } \\
\text { served }\end{array}$ & $\begin{array}{c}\text { Ex- } \\
\text { pected }\end{array}$ & $\begin{array}{l}\text { Ob- } \\
\text { served }\end{array}$ & $\begin{array}{c}\text { Ex- } \\
\text { pected }\end{array}$ & $\begin{array}{l}\text { Ob- } \\
\text { served }\end{array}$ & $\begin{array}{c}\text { Ex- } \\
\text { pected }\end{array}$ & $\begin{array}{l}\text { Ob- } \\
\text { served }\end{array}$ & $\begin{array}{c}\text { Ex- } \\
\text { pected }\end{array}$ \\
\hline All sites & 6 & 3.9 & 7 & 8.3 & 5 & 7.4 & 4 & 4.1 & 22 & 23.7 \\
\hline $\begin{array}{l}\text { Lymphatic and } \\
\text { hematopoietic tissue }\end{array}$ & 2 & 0.6 & - & 0.5 & 2 & 0.3 & - & 0.2 & 4 & 1.6 \\
\hline
\end{tabular}

\section{Histological assessment of the lymphomas}

Histological material was obtained from all three cases for which a notification of non-Hodgkins lymphoma was received from the cancer registry. Three consultant pathologists with particular expertise in the histological classification of lymphomas were asked to classify 30 slides. They were informed of the reason for the exercise but viewed and reported on the slides independently of each other. Five of the slides came from the three lymphoma cases; the remaining 25 being derived from six patients with Hodgkins disease and 19 patients with non-Hodgkins lymphoma. The slides were randomly arranged and given a serial number 1 to 30 . This was the only identification or information about the material available to the pathologists. Each slide was a hematoxylin eosin preparation. The pathologists unanimously identified each case of known Hodgkins disease but gave a non-Hodgkins lymphoma diagnosis to all the slides obtained from the three study cases. For two of these cases, including that classified as Hodgkins disease on the death certificate, they were unanimous, classifying them as centroblastic centrocytic follicular lymphomas. The third case (which was registered for cancer notification and death as nonHodgkin's lymphoma) was variably classified as a plasmablastic lymphoma, a B-cell lymphoma with plasmacytoid cells, and a follicular centroblastic centrocytic lymphoma.

\section{Deaths by cause and age}

Table 2 shows the observed and expected deaths, the standardized mortality ratios based on England and
Wales mortality rates, and, where available, corresponding ratios based on northwest region mortality rates. Fewer deaths were observed than expected from all causes and from all malignant neoplasms, both in the exposed and unexposed populations; the standardized mortality ratios for these causes in the two groups were very close. There were no deaths from leukemia in either the exposed or the unexposed population. The three deaths from lymphomas in the exposed population were in excess of the 0.56 expected, and the excess was statistically significant $\left(\mathrm{P}_{\mathrm{u}}=\right.$ $0.02){ }^{3}$ In contrast, in the unexposed population, there was no such excess, and the standardized mortality ratio of 90 for lymphomas was identical to that for lung cancer, all malignant neoplasms, and all causes of death.

Table 3 shows the observed and expected deaths in the exposed population by age. The results for the 15 to 44-year age group were unusual. Only two deaths were observed, significantly fewer than expected, but both of these were caused by lymphomas. The two lymphoma deaths in the age group exceeded the expected $0.27\left(\mathrm{P}_{\mathrm{u}}=0.032\right)$.

\section{Cancer registrations}

Table 4 shows the observed and expected numbers for all cancers and for lymphohematopoietic neoplasm for the exposed population. For total malignant neoplasms

\footnotetext{
${ }^{3}$ The probability levels quoted in this report are all one-tailed; the notations $P_{u}$ and $P_{1}$ indicate respectively the upper and lower tails of the distribution in question.
} 
Table 5. Observed (Obs) and expected (Exp) registrations (1967-1981) of lymphatic and hematopoietic cancers in the exposed population. (SRR $=$ standardized registration ratio, $I C D=$ International Classification of Diseases)

\begin{tabular}{lrrl}
\hline Type of cancer (ICD code) & Obs & Exp & \multicolumn{1}{c}{ SRR } \\
\hline Lymphoma (200-202) & 3 & 0.8 & $375\left(\mathrm{P}_{\mathrm{u}}=.047\right)$ \\
$\quad$ Lymphosarcoma and & & & \\
reticulosarcoma (200) & 2 & 0.3 &. \\
$\quad$ Hodgkin's disease (201) & - & 0.4 &. \\
$\quad$ Other lymphoma (202) & 1 & 0.1 &. \\
Multiple myeloma (203) & - & 0.2 &. \\
Leukemia (204-209) & 1 & 0.6 &. \\
$\quad$ Lymphatic leukemia (204) & 1 & 0.2 &. \\
$\quad$ Other (205-209) & - & 0.4 &. \\
\hline Total (200-209) & 4 & 1.6 & $250\left(P_{\mathrm{u}}=.079\right)$ \\
\hline
\end{tabular}

the agreement between the observed and expected numbers was close. When the registrations were broken down into more detailed site categories (not shown), an unexpected excess incidence of cancer of the larynx ( 3 observed, 0.5 expected) appeared. The probability ${ }^{4}$ of such an extreme result (standardized registration ratio 600 ) based on three or more cases in any of the 34 detailed site categories examined is 0.041 . An additional unusual feature of the cases was that two of the men were under 45 years of age at the time of the registration ( 0.1 expected). Laryngeal cancer is often amenable to treatment, and no mortality for this cause has been reported for this population. Table 5 shows a detailed breakdown of the observed and expected cancer registrations for lymphatic and hematopoietic cancers.

\section{Levels of exposure}

No measured levels of styrene exposure at the plant exist in a form exploitable in the present study. The styrene production process was enclosed, although the plant itself was not housed in a walled building. The plant was part of a much larger general chemical works, and workers commonly moved from one process to another. It is believed that the exposures of the exposed workers would in general have been well below the hygienic standard of $100 \mathrm{ppm}\left(420 \mathrm{mg} / \mathrm{m}^{3}\right)$ with isolated excursions to higher levels associated with certain faults and some maintenance work.

\section{Length of exposure of the lymphoma/leukemia cases to styrene}

In the absence of any exact knowledge of the levels of styrene (or other chemicals) to which the exposed individuals were subject, and of any way of determining a dose gradient among them, the only available index of individual exposure is length of service though given the pattern of exposure described in the

\footnotetext{
${ }^{4}$ Calculated as the maximum of 34 independent Poisson random variables with means equal to the expected registrations in each site category.
}

previous section, an individual's length of service is likely to be only weakly correlated with the cumulative dose of styrene. Nevertheless, to examine whether length of service was associated with lymphatic and hematopoietic cancer, we compared the length of service of the four cases (three deaths, one registration) to that of individually matched referents. The criteria for the selection of the referents were that the referent's age at his start of service should be within \pm 1 year of the case's age at his start of service and that the referent should have survived alive and cancer-free (no registered cancer) for at least as long after start of service as the case. Apart from the fact that case number 1 had retired, no information was available on the employment history of either the cases or the referents after the end of 1975; for the purposes of this comparison no service after this date was counted. Since none of the cases had service after this date, the effect of this restriction is to understate the length of service of the referents (and probably also to increase the variance of their length of service). Table 6 shows the results of this case-referent comparison. For the two lymphoma cases who were under 40 years of age at death, the lengths of service were 1.5 and 1.3 years, compared to the mean lengths of service of their referents of at least 7.7 and 8.9 years, respectively. The other two cases had lengths of service slightly above the average length of service of their respective referents. There was thus no apparent association between length of service in the styreneexposed jobs and the incidence of lymphatic and hematopoietic cancer.

Table 6 also shows each lymphoma case's known exposure to other chemicals at the site under study. Apart from working in the styrene plants, the worker of case $1 \mathrm{had}$ also worked on the production of styrene/butadiene rubber and would also have had exposure to acrylonitrile, as well as potential exposure to styrene in the monomer plant; case 2 involved potential occupational exposure to benzene; the man in case 3 had worked in plants with potential exposure to dyestuffs, antioxidants, and polyolefines, and case 4 involved potential exposure to ethylene oxide. Benzene, ethylene oxide, some dyestuffs, and certain antioxidants have all been implicated as mutagens or oncogens in man.

\section{Discussion}

The present study had its origins in the aftermath of the discovery of the association between vinyl chloride and angiosarcoma of the liver. The concern was that by virtue of its vinyl structure, styrene (vinyl benzene) might also produce malignancies in man. By the time that the extended process of assembling and flagging the study population and determining the exposure status of the individuals involved had been completed, reports $(3,4,5)$ had appeared in the literature suggesting that exposure to styrene might be associated 
Table 6. Comparison of data on the lymphoma and leukemia cases among the exposed population with that of the matched referents. ${ }^{\text {a }}$ (ICD $=$ International Classification of Diseases)

\begin{tabular}{|c|c|c|c|c|c|c|c|c|c|}
\hline $\begin{array}{l}\text { Case } \\
\text { number }\end{array}$ & $\begin{array}{l}\text { Death certificate } \\
\text { diagnosis } \\
\text { (underlying cause) }\end{array}$ & $\begin{array}{l}\text { Job and date } \\
\text { of first } \\
\text { exposure } \\
\text { to styrene }\end{array}$ & $\begin{array}{l}\text { Other } \\
\text { known } \\
\text { exposures }\end{array}$ & $\begin{array}{l}\text { Age at } \\
\text { death } \\
\text { (years) }\end{array}$ & $\begin{array}{l}\text { Time be- } \\
\text { tween first } \\
\text { exposure } \\
\text { and death } \\
\text { (years) }\end{array}$ & $\begin{array}{c}\text { Duration } \\
\text { of } \\
\text { exposure } \\
\text { (years) }\end{array}$ & $\begin{array}{l}\text { Number } \\
\text { of } \\
\text { referents }\end{array}$ & $\begin{array}{l}\text { Mean } \\
\text { exposure } \\
\text { (years) } \\
\text { of the } \\
\text { referents }\end{array}$ & $\begin{array}{c}\text { Standard } \\
\text { deviation } \\
\text { of exposure } \\
\text { (years) of the } \\
\text { referents }\end{array}$ \\
\hline 1 & $\begin{array}{l}\text { Generalized } \\
\text { reticulum ceil } \\
\text { sarcoma } \\
\text { (ICD 200.0) }\end{array}$ & $\begin{array}{l}\text { Operator } \\
\text { extruder - } \\
\text { polystyrene } \\
(1958)\end{array}$ & $\begin{array}{l}\text { Acrylonitrile, } \\
\text { pitch, polyvi- } \\
\text { nyl chloride } \\
\text { fumes }\end{array}$ & 62 & 16.6 & 6.5 & 12 & 4.3 & 3.8 \\
\hline 2 & $\begin{array}{l}\text { Reticulosar- } \\
\text { coma, mouth } \\
\text { (ICD 200.0) }\end{array}$ & $\begin{array}{l}\text { Trainee ope- } \\
\text { rator - sty- } \\
\text { rene }(1959)\end{array}$ & Benzene & 34 & 4.0 & 1.5 & 44 & 7.7 & 6.2 \\
\hline 3 & $\begin{array}{l}\text { Hodgkin's dis- } \\
\text { ease (ICD 201.0) }\end{array}$ & $\begin{array}{l}\text { Process ope- } \\
\text { rator - } \\
\text { polystyrene } \\
(1960)\end{array}$ & $\begin{array}{l}\text { Dyestuffs, } \\
\text { antioxidants, } \\
\text { polyolefines }\end{array}$ & 37 & 8.0 & 1.3 & 40 & 8.9 & 6.2 \\
\hline 4 & $\begin{array}{l}\text { Chronic lympha- } \\
\text { tic leukemia } \\
\text { (ICD 204.9) }\end{array}$ & $\begin{array}{l}\text { Operator - } \\
\text { styrene } \\
(1960)\end{array}$ & $\begin{array}{l}\text { Ethylene } \\
\text { oxide }\end{array}$ & 59 & 15.9 & 5.8 & 20 & 5.5 & 4.9 \\
\hline
\end{tabular}

a Mean exposure of the cases 3.8 with a stardard deviation of 2.8 ; mean exposure of the referents 6.6 with a standard deviation of 5.4 .

b Cancer registration (not death) for case 4 .

with lymphoma and/or leukemia. It is in this context that the results of the present study should be evaluated.

The patterns of mortality displayed by the exposed and reference groups under observation were broadly very similar. Their standardized mortality ratios of 80 and 90 , respectively, for all causes were typical of what is generally found when a working population is compared with the whole population. The one statistically significant excess cause of mortality was lymphoma in the exposed population.

While there were no deaths recorded as having leukemia as the underlying cause (the expected numbers were 0.3 and 1.5 for the exposed and reference groups, respectively), one exposed individual certified as dying from hypertensive heart disease was also noted on the death certificate as having had chronic lymphatic leukemia. An approximate calculation based on deaths certified in 1976 (the only year for which a full analysis of multiple cause data is available) indicated that the expected number of certificates from the exposed population with any mention of leukemia would be less than 0.4.

In respect to lymphoma and leukemia, the data on cancer registrations (obtained for the exposed population only) tell very much the same story as that based on death certificates.

Overall, the observations of this study are thus consistent with previous reports suggesting an association between styrene exposure and lymphoma/leukemia. In common with the reports by Ott et al (7) and McMichael et al (3), it seems to suggest a specific effect on the lymphatic system. Of the cancer registration data, four cases in the present study fell into the restricted category lymphoma and lymphatic leukemia (ICD 200-202 and 204) and were largely in excess of expectation (4 observed, 1 expected). However, any conclusions drawn from this study must be qualified by the small numbers involved. The lifetime expected number of lymphoma, myeloma, and leukemia cases among the 622 styrene process workers (on the null hypothesis that styrene exposure has no effect) is about 10 , and in the short period of observation so far is 1.6. It is clear that any conclusion based on this result unless enormous excesses were observed - would be very uncertain. A statistical measure of the uncertainty attached to the indication of excess risk by this study is the width of the $95 \%$ confidence interval for the observed standardized mortality ratio (or standardized registration ratio). Over the whole group of lymphomas and leukemia the standardized mortality ratio was 300 with a $95 \%$ confidence interval running from 62 to 880 . The standardized registration ratio for the same cause group was 250 with a confidence interval of $68-640$. If attention is restricted to lymphatic cancer (lymphoma and lymphatic leukemia), the standardized mortality ratio is 450 with a confidence interval of 94-1 330; the standardized registration ratio is 400 , the confidence interval being $110-1020$.

In a consideration of whether this probable excess of non-Hodgkin's lymphoma and leukemia is causally associated with styrene exposure, reliable dose data would have been valuable. Such data were not available, and the intermittent nature of the exposure would make any accurate assessment of individual levels difficult. The lack of association between nonHodgkin's lymphoma, leukemia, and length of employment in potentially exposed jobs would tend to argue against a causal link. However, as has already been mentioned, length of service is probably a rather poor indicator of individual exposure.

A similarly inconclusive argument applies to the implied induction period of the tumors. The delays between first exposure to styrene and the clinical appearance of the cancers were shorter than would normally be expected for occupational cancer, but there are examples of short latency periods for the reticuloendothelial system. The median delay from exposure to death in cases of radiation-induced leuke- 
mia has been estimated (1) at values between 4.5 and 7.5 years, $10 \%$ of the deaths occurring after a delay of three to four years. A study (10) of patients with ankylosing spondylitis who had received X-ray treatment showed an increased risk of leukemia as early as the second year after treatment. The leukemias induced by radiation are of the myeloid type and are not strictly analogous to the excess of lymphatic cancer observed in the present study. It may well be, however, that reticuloendothelial malignancies exhibit shorter induction periods than cancers at other sites.

A possible but unlikely alternative explanation is contagion, which has been suggested to be a factor in the etiology of lymphoma and leukemia (9). All four cases in the present study were engaged in jobs involving styrene contact from November 1960 to March 1961 and in this period would have had at least the possibility of personal contact.

The finding of a quite unanticipated excess (overall observed 3 and expected 0.5 , < 45-year age group observed 2 and expected 0.1 ) of laryngeal cancer cannot be readily interpreted. No similar observations have been reported in the limited epidemiologic literature on styrene, or in that on laryngeal cancer (8). The major risk factor for laryngeal cancer is cigarette smoking. Information on smoking behavior was not available in the present study. Until corroborated or not - by other studies, the observed excess should probably be regarded as a chance event. However, it is intended that further investigation of these cases will be carried out in order to provide more information.

\section{Acknowledgments}

The authors gratefully acknowledge the helpful cooperation of the company involved in the study in extracting information from its records. Also the work of the National Health Service Central Register in tracing and flagging the population is gratefully acknowledged. Several members of the Health and Safety Executive's Medical Statistics Survey Unit were involved in work on the study, in particular Ms S John,
Mr A Mehta, and $\mathrm{Mr} \mathbf{J}$ Scullion. The computer program used in analyzing the data was written by Ms $P$ Dyer of the Computer Division of the Office of Population Censuses and Surveys. We are indebted to Dr MH Bennett, Dr AG Stansfeld, and Professor DH Wright for their help and advice and for reviewing the histology of the lymphoma cases.

\section{References}

1. Armenian HK, Lilienfield AM. The distribution of incubation periods of neoplastic diseases. Am J Epidemiol 99 (1974) 92-100.

2. Frentzel-Beyme R, Thiess AM, Wieland R. Survey of mortality among employees engaged in the manufacture of styrene and polystyrene at the BASF Ludwigshafen Works. Scand J Work Environ Health 4 (1978): suppl 2, 231-239.

3. McMichael AJ, Spirtas R, Gamble JF, Tovsey PM. Mortality among rubber workers: Relationship to specific jobs. J Occup Med 18 (1976) 178-185.

4. National Institute for Occupational Safety and Health. Proceedings of NIOSH styrene-butadiene briefing held at Convington, Kentucky, on 30 April 1976. Cincinnati, OH 1976.

5. Nicholson WJ, Selikoff IJ, Seidman H. Mortality experience of styrene-polystyrene polymerization workers. Scand J Work Environ Health 4 (1978): suppl 2, 247-252.

6. Office of Population Censuses and Surveys. Area mortality tables: Decennial Supplement 1969-73. Her Majesty's Stationery Office, London 1979.

7. Ott MG, Kolesar RC, Scharnweber HG, Schneider EJ, Venable JR. A mortality survey of employees engaged in the development or manufacture of styrene-based products. J Occup Med 22 (1980) 445-460.

8. Rothman XJ, Cann CI, Flanders D, Fried MP. Epidemiology of laryngeal cancer. Epidemiol Rev 2 (1980) 195-209.

9. Schimpff SC, Schimpff CR, Brager DM, Wiernile PA. Leukaemia and lymphoma patients interlinked by prior social contact. Lancet 1 (1975) 124-129.

10. Smith PG, Doll R. Mortality among patients with ankylosing spondylitis after a single treatment course with X-rays. Br Med J 284 (1982) 449-460.

Received for publication: 12 February 1985 